\title{
Cold stratification complements cold water in enhancing the germination of Juniperus procera seeds
}

\author{
Hailu Negussie, Debissa Lemessa*, Seid Melesse, Motuma Didita \\ Department of Forest and Rangeland Plant Biodiversity, Ethiopian Biodiversity Institute, P.O. Box 30726, Addis Ababa, Ethiopia
}

Received: 18.10 .2016

Accepted: 02.01.2017

Published: 29.01 .2017

*Address for correspondence:

Debissa Lemessa, Ethiopian Biodiversity Institute, P.O. Box 30726, Addis Ababa, Ethiopia.

Phone: +251931426444.

E-mail: lemdeb@yahoo.com

\begin{abstract}
Enhancing seed germination is a fundamental step for conservation of plant genetic resources, but less is understood specifically for endangered native and endemic tree species in the tropics. We examined how cold stratification and application of different treatments impact the germination of Juniperus procera seeds. We collected seeds from nine different altitudes of Managesha forest, Oromia region, Ethiopia. The seeds were stored in gene bank at $-10^{\circ} \mathrm{C}$ for 4 years for cold stratification as a dormancy-breaking method. We employed three treatments: Cold water, $70^{\circ} \mathrm{C}$ hot water, and $100 \mathrm{ml}$ of $1 \% \mathrm{H}_{2} \mathrm{O}_{2}$ to setup germination experiment in completely randomized design with four replications ( 50 seeds each). The germinated seeds were counted for every $5^{\text {th }}$ day until no more germinated seeds were observed. We analyzed data using two-way analysis of variance, and the significant for mean difference among altitudinal gradients was computed with Tukey HSD tests. The germination percent from cold stratified and moistened in cold water was higher than either from control, soaking in $70^{\circ} \mathrm{C}$ hot water or applying $1 \% \mathrm{H}_{2} \mathrm{O}_{2}$ solution. Moreover, the germination percent varied among the altitudinal gradients for all the three treatments. At some altitudes, the germination was higher or lower consistently throughout control and the three treatments. The variations in altitudinal gradient and the associated environmental factors have triggered the differences in germinability of $J$. procera seeds. Our overall results suggest that cold stratification can complement cold water to break the dormancy and enhance the germination of $\mathrm{J}$. procera seeds.
\end{abstract}

KEY WORDS: Cold stratification, dormancy, gene bank, germination, treatments

\section{INTRODUCTION}

Juniperus procera Hoechst. Ex Endl. (J. procera, hereafter), belongs to the Cupressaceae family, is an evergreen, highland, tropical, dioecious tree species commonly growing between 1800 and $3200 \mathrm{~m}$ a.s.l. altitudes (von Breitenbach, 1963). J. procera has a wide ecological distribution from Yemen, Saudi Arabia, to southern and eastern Africa (Friis, 1992). In Ethiopia, it grows individually spread but also can be found forming populations more in dry evergreen afromontane forest and grassland complex ecosystem of Ethiopia (Friis et al., 2010).

J. procera tree produces strong timber that resists termite attack, and for this reason, mainly due to logging, its population is highly fragmented; currently, only small populations are observable, and due to this, it is now one of the threatened tree species in Ethiopia (Farjon, 2013).
J. procera is a dioecious tree species and depends on wind for pollination which would, therefore, be more effective only where reproductively well-matured male and female trees are growing close to each other and it generally has poor seed setting and poor natural regeneration (Negash, 2002). Moreover, under normal condition (for example, on nursery beds), Mamo et al. (2006) found that germination of J. procera is low (12-30\%) though they reported that continuously exposing the seeds to light enhances germination. Hence, it is extremely important to give priority for the conservation of this tree species, for example, by enriching the populations through seedling production. To this end, seeking for mechanisms that significantly but parsimoniously enhance the germination of $J$. procera is super imperative. Here, we used three treatments, i.e., moistening in cold water, soaking in $70 \%$ hot water, and application of $\mathrm{H}_{2} \mathrm{O}_{2}$ solution to test their effects on the germination of $J$. procera seeds collected from different altitudinal gradients and stored in cold gene 
bank for 4 years at $-10^{\circ} \mathrm{C}$. Moreover, we examined the variation in germination among the nine sites - J. procera seeds collected from different altitudinal gradients and aspects in and around Managesha forest, Oromia region, central Ethiopia.

J. procera is among the four endangered indigenous tree species (Hagenia abyssinica, Podocarpus falcatus, and Cordia africana) that the conservation priority was given in Ethiopia. However, among other factors such as anthropogenic impact, the seed dormancy has impeded the artificial restoration of $J$. procera (Teketay, 1993). For this reason, different dormancy breaking methods such as scarification and hot water have been tried (Albrecht, 1993), but it was found that the type of dormancy that the seeds of $J$. procera exhibit was both physiological and physical (Teketay, 1993). Other findings also showed that the $J$. procera seeds exhibit photodormancy (Teketay and Granström, 1997; Yirdaw and Lei-Nonen, 2002). These studies were based only on the fresh seed bulks collected or on single seed lot. Few studies have investigated the effect of stratification amalgamating with other treatments to improve germination of $J$. procera seeds (Mamo et al., 2006). Therefore, less was understood on how to improve the germination of $J$. procera seeds, particularly for those stored in cold gene bank in Ethiopia. Hence, in this study, we hypothesized that (1) Cold stratification in gene bank breaks seed dormancy and this effect would be higher when the seeds are further moistened in cold water than either in soaking in hot water or applying hydrogen peroxide $\left(\mathrm{H}_{2} \mathrm{O}_{2}\right)$ solution, (2) the effect of the cold stratification and moistening in cold water on the germination capacity varies by altitudinal difference in most plant species due to the variation in environmental factors (Thomsen and Kjaer, 2002; Loha et al., 2006; Mamo et al., 2006).

Our overall results showed that after a cold stratification in gene bank at $-10^{\circ} \mathrm{C}$ for 4 years, the germination percent was higher for seeds moistened in cold water when compared with the control and treatments such as soaking in hot water and in $100 \mathrm{ml}$ of $1 \% \mathrm{H}_{2} \mathrm{O}_{2}$ solution. The germination percent also varied by the interaction between altitudinal gradients and treatments.

\section{METHODOLOGY}

The study area, Managesha forest and the surrounding, is located in West Showa, Oromia National Regional State, Central Ethiopia, at $30 \mathrm{~km}$ from Addis Ababa to the west $\left(8^{\circ} 56^{\prime}-9^{\circ} 00^{\prime} \mathrm{N}\right.$ and $38^{\circ} 31^{\prime}-38^{\circ} 35^{\prime} \mathrm{E}$ ) (Figure 1). It is part of the central plateau with a rugged topographic feature within the altitudinal range of 2200-3385 m a.s.l. (Bekele, 1994). The soil of the study area varies in color from reddish brown at lower altitude to light brown at higher altitudes of the area. According to the information from the nearest one weather station of the National Meteorological Agency, the area gets mean annual rainfall of $1314 \mathrm{~mm}$ with unimodal pattern that peaks during July-August, mean annual temperature of $17^{\circ} \mathrm{C}$. Managesha forest belongs to the dry evergreen afromontane forest and grassland complex ecosystem (Friis et al., 2010). It comprises the dominant tree species including J. procera, Olea europaea, P. falcatus, Allophylus abyssinicus, Croton macrstachyus, Maytenus sp., Osyris quadripartita, and Euphorbia ampliphylla, and at the upper altitudinal limit, the common shrubs growing are Erica spp. (heather) and Helichrysum species.

\section{Germination Experiment}

The seeds of J. procera were collected during 17-23 June 2006 from nine sites of different altitudes (2460-2880 m a.s.l.) of the Managesha forest (Table 1). The minimum and maximum distance between the two sites from where the seeds were collected are 0.2 and $5 \mathrm{~km}$, respectively (Figure 2). At each site, seeds were collected from the top, middle, and lower parts of the crown of randomly selected four mother trees. And at each site, the seeds collected from four trees were mixed together and stored in the plastic bags. At the seed processing laboratory, these seeds were cleaned and fumigated to make free from pests, and using the information of the seed passport data, the code was given for each of the seeds collected from different altitudinal gradients of the Managesha forest (Table 1). Thereafter, seeds that were to be used as controls were directly exposed to germination test without modifying moisture content. However, the seeds intended to be stored for cold stratification were dried in an oven with $103^{\circ} \mathrm{C}$, moisture content was reduced to $3-4 \%$, and packed with aluminum foil, and then we stored them in cold gene bank of Ethiopian Biodiversity Institute at $-10^{\circ} \mathrm{C}$ for 4 years (2007-2011).

Table 1: Geographic locations, altitudes, and aspects from where seeds of Juniperus procera tree species were collected

\begin{tabular}{lcccl}
\hline Sites & Latitude & Longitude & Altitude (m a.s.I.) & Aspect \\
\hline $\mathrm{A}$ & $09^{\circ} 02^{\prime} 03^{\prime \prime} \mathrm{N}$ & $38^{\circ} 35^{\prime} 31^{\prime \prime} \mathrm{E}$ & 2880 & East \\
$\mathrm{B}$ & $09^{\circ} 03^{\prime} 21^{\prime \prime} \mathrm{N}$ & $38^{\circ} 34^{\prime} 38^{\prime \prime} \mathrm{E}$ & 2540 & Northwest \\
$\mathrm{C}$ & $09^{\circ} 02^{\prime} 05^{\prime \prime} \mathrm{N}$ & $38^{\circ} 35^{\prime} 26^{\prime \prime} \mathrm{E}$ & 2870 & Northeast \\
$\mathrm{D}$ & $09^{\circ} 02^{\prime} 23^{\prime \prime} \mathrm{N}$ & $38^{\circ} 35^{\prime} 24^{\prime \prime} \mathrm{E}$ & 2837 & Northeast \\
$\mathrm{E}$ & $09^{\circ} 03^{\prime} 43^{\prime \prime} \mathrm{N}$ & $38^{\circ} 33^{\prime} 34^{\prime \prime} \mathrm{E}$ & 2565 & Northwest \\
$\mathrm{F}$ & $09^{\circ} 01^{\prime} 60^{\prime \prime} \mathrm{N}$ & $38^{\circ} 35^{\prime} 02^{\prime \prime} \mathrm{E}$ & 2646 & South \\
$\mathrm{G}$ & $09^{\circ} 02^{\prime} 05^{\prime \prime} \mathrm{N}$ & $38^{\circ} 35^{\prime} 00^{\prime \prime} \mathrm{E}$ & 2460 & Southwest \\
$\mathrm{H}$ & $09^{\circ} 02^{\prime} 17^{\prime \prime} \mathrm{N}$ & $38^{\circ} 35^{\prime} 12^{\prime \prime} \mathrm{E}$ & 2700 & North \\
$\mathrm{I}$ & $09^{\circ} 02^{\prime} 15^{\prime \prime} \mathrm{N}$ & $38^{\circ} 34^{\prime} 59^{\prime \prime} \mathrm{E}$ & 2600 & Northwest \\
\hline
\end{tabular}




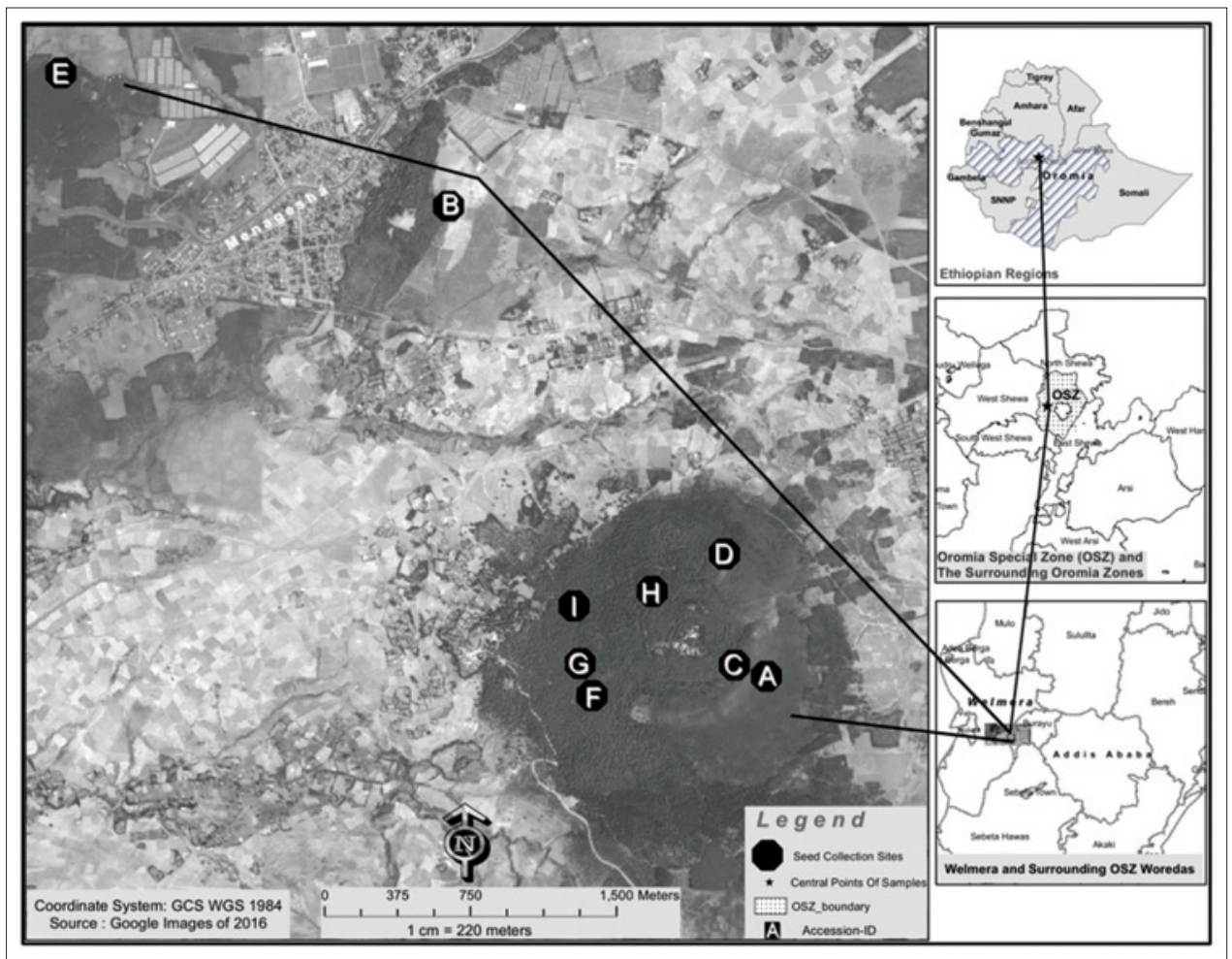

Figure 1: The map showing the Managesha forest sites. The letters (A-I) shown in the map are the GPS points from where the seeds of Juniperus procera were collected

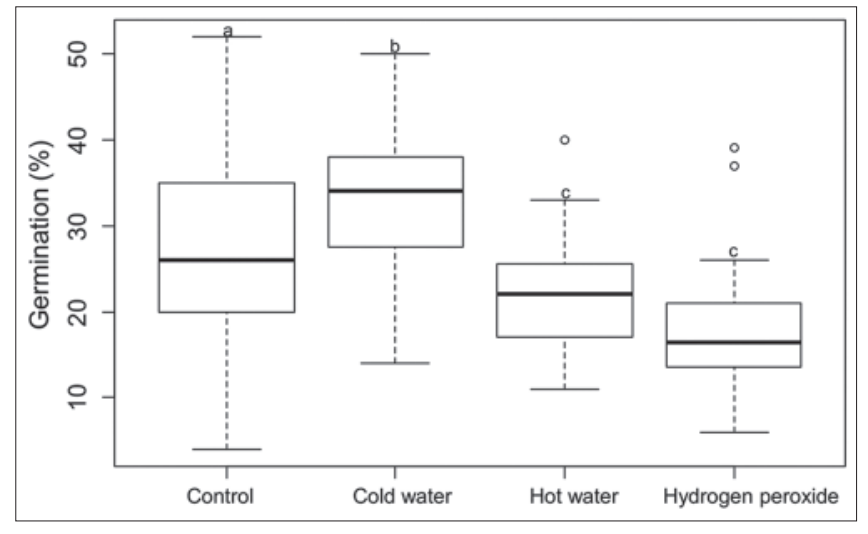

Figure 2: The boxplot showing the effect of the combination of cold stratification and treatments on the seed germination of Juniperus procera. The Tukey HSD test multiple comparison of the means showed that germination percent is higher using cold water treatment when compared with control, hot water, or $1 \%$ hydrogen peroxide solution. The different lower case letters in the figure indicate the significant differences $(\alpha=0.01)$

\section{Control}

200 seeds that were well mixed were randomly sampled separately from each altitudinal gradient and divided into four (i.e., 50 seeds) replications. The seeds were placed and spread on Petri dish containing filter paper which was moistened with deionized water. The Petri dish containing seeds was arranged in randomized complete design in a growing chamber at room temperature $\left(\sim 25^{\circ} \mathrm{C}\right)$ and allowed to germinate. Deionized water was added into Petri dish as necessary to keep it moist for seed germination. The number of germinated seeds, i.e., when the radicle developed to about $2 \mathrm{~mm}$ and attained a normal appearance (Tigabu et al., 2007), was counted for every $5^{\text {th }}$ day until no additional germinated seeds were observed.

\section{Cold Water}

From the cold-stratified seeds at $-10^{\circ} \mathrm{C}$ for 4 years, 200 seeds that were well mixed were randomly sampled separately from each altitudinal gradient and divided into four (i.e., 50 seeds) replications. The seeds were placed and spread on Petri dish containing filter paper which was moistened with deionized water. The Petri dish containing seeds was arranged in randomized complete design in a growing chamber at room temperature $\left(\sim 25^{\circ} \mathrm{C}\right)$ and allowed to germinate. Regular monitoring has been made, and deionized water was added into Petri dish as necessary to keep it moist for seed germination. The number of germinated seeds was counted for every $5^{\text {th }}$ day until no additional germinated seeds were observed for the 60 consecutive days.

\section{Hot Water}

The same procedure and arrangement used for cold water treatment was also applied for hot water treatment. 
However, here, the seeds were soaked in $70^{\circ} \mathrm{C}$ hot water before the germination test was ran. To determine the optimum soaking time, we performed a pre-test assessment by sampling five seeds from each type soaking in $70^{\circ} \mathrm{C}$ hot water for $1,3,5$, and $7 \mathrm{~min}$ (i.e., with $2 \mathrm{~min}$ interval) and checked the germination for 30 consecutive days. The result of our pre-test showed that those seeds soaked for $7 \mathrm{~min}$ performed higher germination percent (two-way analysis of variance [ANOVA], $P<0.001$, data not shown). Subsequently, the actual test was made by soaking in $70^{\circ} \mathrm{C}$ hot water for $7 \mathrm{~min}$, and the germinated seeds were counted for every $5^{\text {th }}$ day until no additional germinated seeds were observed for the 60 consecutive days.

\section{$\mathrm{H}_{2} \mathrm{O}_{2}$}

To apply the $\mathrm{H}_{2} \mathrm{O}_{2}$ treatment, we followed the procedure set by Laedem (1984, cited in Schmidt, 2000). The application of $\mathrm{H}_{2} \mathrm{O}_{2}$ solution increases the supply of oxygen and speeds up germination initiation. Most often, $\mathrm{H}_{2} \mathrm{O}_{2}$ is used as a pretreatment since it removes the blockage of abscisic acid and germination delaying or inhibitions (Çavuşoğlu and Kabar, 2010). Accordingly, from each altitudinal gradient, 200 seeds were soaked in $100 \mathrm{ml}$ of $1 \% \mathrm{H}_{2} \mathrm{O}_{2}$ overnight. The radicle end of seeds was carefully removed by cutting off using blade and the cut seeds were transferred into $150 \mathrm{ml}$ of $1 \% \mathrm{H}_{2} \mathrm{O}_{2}$. These seeds were incubated in dark at room temperature $\left(\sim 25^{\circ} \mathrm{C}\right)$ for 3 days, and on the $3^{\text {rd }}$ day, the observed radicles were cut off from each seed. As the next step, from each altitudinal gradient, 200 seeds were arranged with four replications (i.e., 50 seeds each), and $1 \% \mathrm{H}_{2} \mathrm{O}_{2}$ solution was renewed and seeds were incubated for 4 additional days and then allowed to germinate on Petri dish for 7 days, and the germinated seeds were counted on the $7^{\text {th }}$ day. Hencefor th, the germinated seeds were counted for every $5^{\text {th }}$ day until no additional germinated seeds were observed for 60 consecutive days.

\section{Statistical Analysis}

The germination percent was calculated as the number of seeds germinated divided by the total number of seeds (i.e., 50 seeds per replication) placed on Petri dish multiplied by 100 . This means germination percent was calculated for each replication in each respective altitudinal gradient.

To test the effect of the treatments and altitudinal gradient on germination of $J$. perocera seeds, we ran two-way ANOVA (main factors and interaction of: Control 'treatment + control' altitude + treatment ' altitude).
Moreover, to test the differences in germination capacity among altitudinal gradients, we employed one-way ANOVA. After we found the significant effect of the interaction between treatments and altitudinal gradient on germination, we computed mean separation or multiple comparison of the means using Tukey HSD tests.

\section{RESULTS AND DISCUSSION}

The two-way ANOVA showed that the germination percent of $J$. procera seeds differed by the interaction between treatments and altitudinal gradient (ANOVA, $\left.\mathrm{F}_{(24,108)}, P=0.001\right)$. The germination percent was higher for the seeds cold stratified and moistened in cold water when compared with control, hot water, or $\mathrm{H}_{2} \mathrm{O}_{2}$ solution (HSD Tukey test, $P<0.001$ ) (Figure 2). However, the germination percent of the seeds that were cold stratified and subjected to the treatments such as hot water and $\mathrm{H}_{2} \mathrm{O}_{2}$ solution was lower compared to the control (HSD Tukey test, $P<0.04$ ) (Figure 2). There is no significant difference between the treatments of hot water and $\mathrm{H}_{2} \mathrm{O}_{2}$ solution on the germination of $J$. procera seeds (HSD Tukey test, $P<0.18$ ) (Figure 2).

The mean (mean \pm standard deviation) range of germination percent from control was $12 \pm 7.3-44.5 \pm 7.7 \%$ and for the treatments, it is as follows: Cold water $(47 \pm 4.8 \%-83.5 \pm 19.1 \%)$, hot water $(29.5 \pm 6-66 \pm 10.7 \%)$, and $\mathrm{H}_{2} \mathrm{O}_{2}$ solution (21.5 $\pm 5.7 \%-60 \pm 18.6 \%)$. The mean germination percent was higher at altitudinal gradient $(B=2540 \mathrm{~m}$ a.s.l. $)$, while the lower percent was observed at altitudinal gradient of $F=2646 \mathrm{~m}$ a.s.l. across control and all treatments, besides the germination percent was lower at altitude $(F)$ using cold water treatment (Figure 3).

Understanding how to enhance the seed germination of plants is fundamental to devise effective conservation of genetic resources. It is of paramount importance peculiarly for endangered tree species such as J. procera and others. We report that cold stratification of $J$. procera seeds in seed bank for 4 years at $-10^{\circ} \mathrm{C}$ and moistening in cold water enhance germination better than soaking in $70^{\circ} \mathrm{C}$ hot water or applying $\mathrm{H}_{2} \mathrm{O}_{2}$ treatment (Figure 2). Here, the mean germination percent from moistening in cold water was higher by $6.4 \%$ than control, by $11.9 \%$ than hot water, and by $15.9 \%$ than $\mathrm{H}_{2} \mathrm{O}_{2}$. Our result is in line with the previous studies which proposed that cold storage enhances the germination of J. procera seeds (Mamo et al., 2011). The most likely reason for such effect is that cold stratification may break the physical dormancy as it was suggested by previous findings (Teketay, 1993; Baskin 


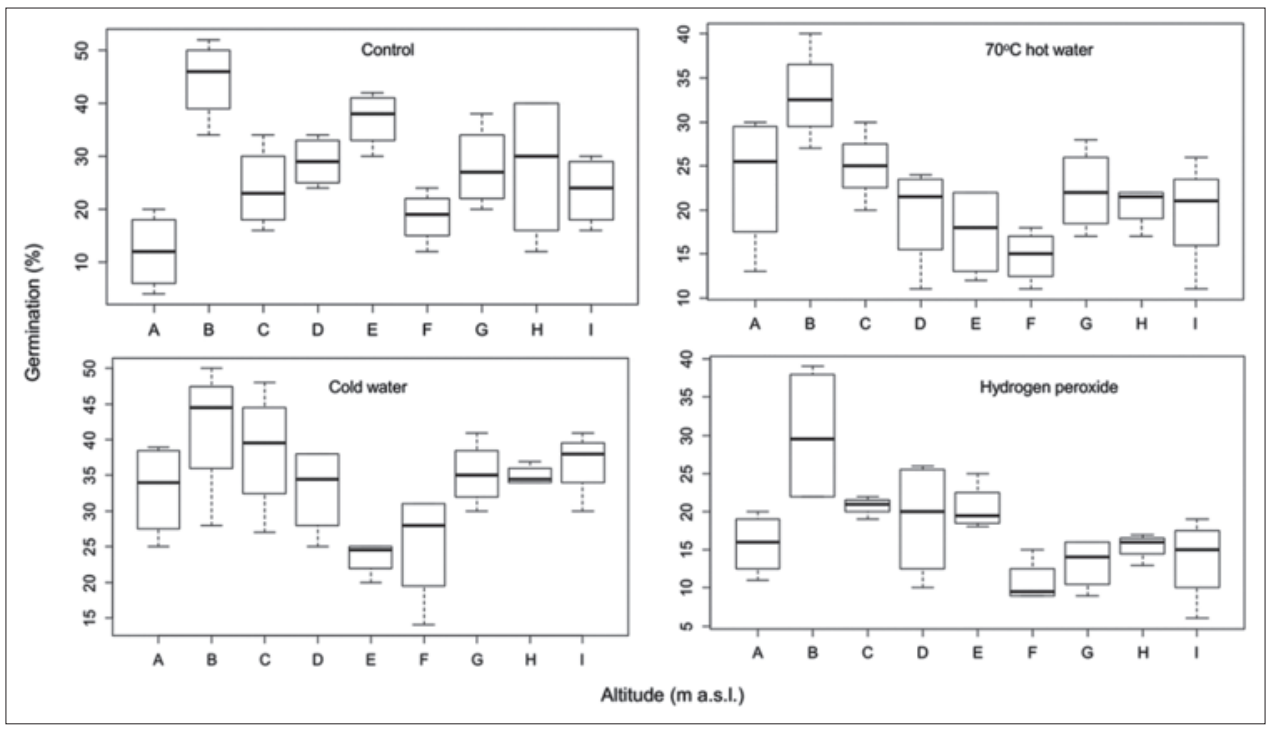

Figure 3: The boxplots showing the germination percent of Juniperus procera seeds across the nine altitudes (A-I), control, and three treatments: Cold water, hot water, and hydrogen peroxide $\left(\mathrm{H}_{2} \mathrm{O}_{2}\right)$. Here, while the germination percent was higher at altitude $(B)$ for control and all of the three treatments, it was lower at altitude $(E)$ with cold water treatment and at altitude $(F)$ with hot water and $\mathrm{H}_{2} \mathrm{O}_{2}$ treatments. Seed collection sites and altitude gradients were shown in Table 1

and Baskin, 1998; Mamo et al., 2011). The germination percent from seeds soaked in $70^{\circ} \mathrm{C}$ hot water and $\mathrm{H}_{2} \mathrm{O}_{2}$ solution was even less than the control (Figure 2). Nevertheless, the germination percent for seeds soaked in $70^{\circ} \mathrm{C}$ hot water for $7 \mathrm{~min}$ was also higher when compared with the germination by applying $\mathrm{H}_{2} \mathrm{O}_{2}$ solution (Figure 2). Our result of the effect of hot water on the germination of $J$. procera seeds also corroborates the earlier finding of Albrecht (1993) who found that hot water breaks the dormancy of $J$. procera seeds, but contradicts the result found by Teketay (1993) who denoted hot water results in a germination failure.

The germination percent of $J$. procera seeds significantly varies among altitudinal gradients (Figure 3). Here, the germination percent was higher for altitude $(B)$ for control and all the three treatments, while it was lower for altitude $(E)$ with cold water and lower for altitude $(F)$ with hot water and $\mathrm{H}_{2} \mathrm{O}_{2}$ treatments (Figure 3 ). The possible reason for this variation could be that the seeds were collected from different altitudinal gradients and aspects, the topography toward which the slope faces (Table 1). The differences in edaphic factors, microclimate, and habitat conditions among altitudes may have influenced the variability in seed germination potentiality of $J$. procera seeds (Friis, 1992; Thomsen and Kjaer, 2002; Moles and Westoby, 2004; Tigabu et al., 2007; Mamo et al., 2011). The environmental stresses vary across sites or altitudes and their respective impacts on resource allocation, total reproductive outputs-flowers, fruits/seeds, and on germination potential may also correspondingly vary
(Bazzaz et al., 2000). Nevertheless, since we collected seeds randomly from the different positions or heights of the tree crown and also we did not consider the variation in age, we could not avoid their confounding effect in the observed significant differences in germination among sites or altitude differences (Wulff, 1995; Gutterman, 2000). Despite this reality, our finding provides a clear evidence for the possibility of enhancing the germination of $J$. procera seeds to conserve the species either using artificial plantation or by establishing ex situ conservation. To this end, exploring for germination-enhancing mechanism is of paramount importance, for example, optimizing the cold stratification period and temperature (Tigabu et al., 2007). Our study was based only on one period of cold stratification (i.e., 4-year storage) and temperature level $\left(-10^{\circ} \mathrm{C}\right)$ and did not examine using different cold storage length of times and temperature levels to find the optimum period that may enhance the germination further in interaction with the treatments, for example, using cold water or others. Our overall result underscores that complementing cold water with cold stratification enhances the germination of $J$. procera seeds when compared with either soaking in hot water or applying $\mathrm{H}_{2} \mathrm{O}_{2}$ solution.

The present study shows that germination percent of $J$. procera seeds was higher for seeds cold stratified in gene bank for 4 years at $-10^{\circ} \mathrm{C}$ and moistened in cold water when compared with control and other treatments - cold stratification + soaking seeds in hot water and cold stratification $+\mathrm{H}_{2} \mathrm{O}_{2}$. Yet, the germination percent from 
all the three treatments varied among altitudes for all the treatments. In this regard, at the altitudes where germination percent was higher and lower on control seeds, they also had similar respective trends with cold water, hot water, and $\mathrm{H}_{2} \mathrm{O}_{2}$ solution. In our study, we used only one period of cold stratification (i.e., 4-year storage) and one temperature level $\left(-10^{\circ} \mathrm{C}\right)$ and $\operatorname{did}$ not examine using different length of times and temperature levels to find the optimum period and hence we suggest further study to boost the germination further combining with the treatments such as cold water and others. In conclusion, our results suggest that the combination of cold stratification and cold water can be used to break the dormancy and enhance the germination of $J$. procera seeds.

\section{ACKNOWLEDGMENTS}

First of all, we would like to thank the Ethiopian Biodiversity Institute for fund support. Next, we are deeply indebted to Tadele Zewdie, Tesfaye Awas, Eleni Shiferaw, and Basazen Fantahuan for their constructive comments. Finally, our sincere thanks goes to Sebelework Belayneh and Tsehay Mulaw for their wholehearted technical assistance.

\section{REFERENCES}

Albrecht J. Tree Seed Handbook of Kenya. Maguga, Kenya: GTZ Forest Seed Centre; 1993.

Baskin CC, Baskin JM. Seeds: Ecology, Biogeography, and Evolution of Dormancy and Germination. San Diego: Academic Press; 1998.

Bazzaz FA, Ackerly DD, Reekie EG. Reproductive allocation in plants. In: Fenner M, editor. Seeds: The Ecology of Regeneration in Plant Communities. Wallingford, New York: CABI Publishing; 2000. p. 1-29.

Bekele T. Phytosociology and ecology of a humid afromontane forest on the central plateau of Ethiopia. J Veg Sci 1994;5:87-98.

Çavuşoğlu K, Kabar K. Effects of hydrogen peroxide on the germination and early seedling growth of barley under $\mathrm{NaCl}$ and high temperature stresses. Eurasian J Biosci 2010;79:70-9.

Farjon A. Juniperus procera. The IUCN Red List of Threatened Species; 2013: e.T33217A2835242. Available from: http:/ / www.dx.doi.org/10.2305/IUCN.UK.2013-1. RLTS.T33217A2835242.en. [Last downloaded on 2016 Jun 28].

Friis I. Forests and Forest Trees of North East Tropical Africa.
Kew Bulletin, Additional Series XV. London: HMSO; 1992.

Friis I, Demissew S, van Breugel P. Atlas of the potential vegetation of Ethiopia. Det Kongelige Danske Videnskabernes Selska, SpecialtrykkerietViborg a-s, Copenhagen, Denmark; 2010.

GuttermanY. Maternal effects on seeds during development. In: Fenner M, editor. Seeds: The Ecology of Regeneration in Plant Communities. $2^{\text {nd }}$ ed.Wallingford, NewYork: CABI Publishing; 2000. p. 59-84.

Loha A, Tigabu M, Teketay D, Lundkvist K, Fries A. Provenance variation in seed morphometric traits, germination and seedling growth of Cordia africana Lam. New Forest 2006;32:71-86.

Mamo N, Mihretu M, Fekadu M,Tigabu M, Teketay D. Variation in seed and germination characteristics among Juniperus procera populations in Ethiopia. Forest Ecol Manage 2006;225:320-7.

Mamo N, Nigusie D, Tigabu M, Teketay D, Fekadu M. Longevity of Juniperus procera seed lots under different storage conditions: Implications for ex situ conservation in seed banks. J Forest Res 2011;22:453-9.

Moles AT, Westoby M. Seedling survival and seed size: A synthesis of the literature. J Ecol 2004;92:372-83.

Negash L. Successful vegetative propagation techniques for the threatened African pencil cedar (Juniperus procera Hoechst Ex Endl.). Forest Ecol Manage 2002;161:53-64.

Teketay D, Granström A. Germination ecology of forest species from the highlands of Ethiopia. J Trop Ecol 1997; 14:793-803.

Teketay D. Problems associated with raising trees from seeds. In: Lieth H, Lohmann M, editors. Restoration of Tropical Forest Ecosystems. Dordrecht: Kluwer; 1993. p. 91-100.

Thomsen KA, Kjaer ED. Variation between single tree progenies of Fagus sylvatica in seed traits, and its implications for effective population numbers. Silvae Genet 2002;51:183-90.

Tigabu M, Fjellström J, Odén, PC, Teketay D. Germination of Juniperus procera seeds in response to stratification and smoke treatments, and detection of insect-damaged seeds withVIS + NIR spectroscopy. New Forest 2007;33:155-69.

Von Breitenbach F. The Indigenous Trees of Ethiopia. $2^{\text {nd }}$ ed. Addis Ababa, Ethiopia: Ethiopian Forestry Association; 1963.

Wulff RD. Environmental maternal effects on seed quality and germination. In: Kigel J, Galili G, editors. Seed Development and Germination. New York, Basel, Hong Kong: Marcel Dekker Inc.; 1995. p. 491-505.

Yirdaw E, Lei-Nonen K. Seed germination responses of four Afromontane tree species to red/far-red ratio and temperature. Forest Ecol Manage 2002;168:53-61. 